Atmos. Chem. Phys., 18, 8589-8599, 2018

https://doi.org/10.5194/acp-18-8589-2018

(c) Author(s) 2018. This work is distributed under

the Creative Commons Attribution 4.0 License.

\title{
Subgrid-scale variability in clear-sky relative humidity and forcing by aerosol-radiation interactions in an atmosphere model
}

\author{
Paul Petersik, Marc Salzmann, Jan Kretzschmar, Ribu Cherian, Daniel Mewes, and Johannes Quaas \\ Leipzig Institute for Meteorology, Universität Leipzig, Leipzig, Germany \\ Correspondence: Paul Petersik (paul.j.petersik@gmail.com)
}

Received: 7 September 2017 - Discussion started: 13 November 2017

Revised: 17 May 2018 - Accepted: 19 May 2018 - Published: 19 June 2018

\begin{abstract}
Atmosphere models with resolutions of several tens of kilometres take subgrid-scale variability in the total specific humidity $q_{\mathrm{t}}$ into account by using a uniform probability density function (PDF) to predict fractional cloud cover. However, usually only mean relative humidity, $\overline{\mathrm{RH}}$, or mean clear-sky relative humidity, $\overline{\mathrm{RH}}_{\mathrm{cls}}$, is used to compute hygroscopic growth of soluble aerosol particles. While previous studies based on limited-area models and also a global model suggest that subgrid-scale variability in RH should be taken into account for estimating radiative forcing due to aerosol-radiation interactions (RFari), here we present the first estimate of RFari using a global atmospheric model with a parameterization for subgrid-scale variability in $\mathrm{RH}$ that is consistent with the assumptions in the model. For this, we sample the subsaturated part of the uniform RH-PDF from the cloud cover scheme for its application in the hygroscopic growth parameterization in the ECHAM6-HAM2 atmosphere model. Due to the non-linear dependence of the hygroscopic growth on $\mathrm{RH}$, this causes an increase in aerosol hygroscopic growth. Aerosol optical depth (AOD) increases by a global mean of $0.009(\sim 7.8 \%$ in comparison to the control run). Especially over the tropics AOD is enhanced with a mean of about 0.013 . Due to the increase in AOD, net top of the atmosphere clear-sky solar radiation, $\mathrm{SW}_{\text {net,cls }}$, decreases by $-0.22 \mathrm{~W} \mathrm{~m}^{-2}(\sim-0.08 \%)$. Finally, the RFari changes from -0.15 to $-0.19 \mathrm{~W} \mathrm{~m}^{-2}$ by about $31 \%$. The reason for this very disproportionate effect is that anthropogenic aerosols are disproportionally hygroscopic.
\end{abstract}

\section{Introduction}

Aerosols have a significant impact on the climate system by interacting with radiation and clouds. Solar and thermal radiation interact with aerosols by absorption and scattering processes. Despite extensive research on atmospheric aerosols, the effective radiative forcing due to aerosol-radiation interactions (ERFari) has still a large uncertainty. The ERFari combines effects from radiative forcing due to aerosolradiation interactions (RFari) and rapid adjustments and is estimated to be -0.45 ( -0.95 to +0.05$) \mathrm{W} \mathrm{m}^{-2}$ by the 5 th assessment report (AR5) of the Intergovernmental Panel on Climate Change (IPCC; Boucher et al., 2013). The radiative forcing by aerosol-radiation interactions from sulfate $\left(-0.4 \mathrm{~W} \mathrm{~m}^{-2}\right)$ and nitrate $\left(-0.11 \mathrm{Wm}^{-2}\right)$ is a cooling effect on the radiative balance of the Earth due to increased scattering of solar radiation. In contrast, black carbon $\left(+0.4 \mathrm{~W} \mathrm{~m}^{-2}\right)$ is warming the Earth's climate due to absorption of solar radiation. Additionally, it is uncertain if primary and secondary organic aerosols, aerosols from biomass burning and mineral dust have a net cooling or a warming effect (e.g. Bond et al., 2013; Shindell et al., 2013; Myhre et al., 2013; Ginoux, 2017). In total, anthropogenic aerosols have very likely a cooling effect through aerosol-radiation interactions on the radiative balance of the Earth (Boucher et al., 2013).

Through non-linear relationships described by the BeerLambert law (Lambert, 1760; Beer, 1852) and Mie scattering (Mie, 1908), the extinction of radiation is related to the aerosol particle radius. The aerosol particle radius of hygroscopic aerosols like sulfate or sea salt aerosols increases in a humid environment due to attraction of water. This hygroscopic growth is a non-linear function of the ambient relative humidity $(\mathrm{RH})$, where hygroscopic growth is especially 
enhanced close to saturation (Köhler, 1936). Therefore, extinction due to hygroscopic aerosols increases strongly when the humidity of the ambient air approaches saturation (Zieger et al., 2013; Skupin et al., 2016; Haarig et al., 2017).

It is known that humidity varies on subgrid scales in general circulation models (GCMs) with largest subgrid-scale variability in the middle troposphere (e.g. Quaas, 2012). However, GCMs that just use the grid-box mean relative humidity $\overline{\mathrm{RH}}$ to calculate hygroscopic growth of aerosols do not take this subgrid-scale variability in humidity and its effect on radiation into account. Studies based on limited-area models suggest that GCMs may underestimate the RFari of sulfate aerosols by 30 to $80 \%$ when not considering subgridscale variability in RH for the hygroscopic growth of sulfate particles (Haywood et al., 1997; Petch, 2001; Myhre et al., 2002). These studies use high-resolution models and compare the results from calculations of radiative forcing that keep the high resolution of RH with either calculation where $\mathrm{RH}$ is averaged spatially beforehand to mimic a GCM resolution or results from model configurations with a coarser resolution. In addition, recent studies show that models with a coarse resolution which do not take subgrid-scale variability in various aerosol properties into account underestimate aerosol radiative forcing (Gustafson et al., 2011), and have a significant negative bias in aerosol optical depth (AOD; Weigum et al., 2016).

First attempts to implement a subgrid-scale variability in RH in a GCM for the calculation of RFari by sulfate were made by Haywood and Shine (1997) and Haywood and Ramaswamy (1998). However, these studies make strong simplifications about the shape of the used probability density function (PDF) and are not consistent with the cloud cover scheme. Haywood and Shine (1997) prescribe the RH distribution globally for clear skies. For each grid cell and height level, five fixed RH values are taken from a normal distribution around $\mathrm{RH}=70 \%$. They find that RFari by sulfate is $24 \%$ greater than the non-hydrated forcing when using the grid-box mean RH. However, RFari by sulfate increases up to $37 \%$ when the subgrid-scale variability in RH is applied and the correlation between clouds and areas of high relative humidity is taken into account. Hence, RFari by sulfate increased by about $10 \%$ from simulations that use gridbox mean RH to simulations with a subgrid-scale variability in RH. Haywood and Ramaswamy (1998) have a more sophisticated approach. They use a triangular-shaped relative humidity distribution around the grid-box mean $\mathrm{RH}$ with a magnitude of $\pm 10 \%$ that is truncated at $\mathrm{RH}=1.0$ as proposed by Haywood et al. (1997). They show that RFari by sulfate is enhanced by $9 \%$ due to the subgrid-scale variability in RH when clouds are included. We want to point out that Haywood and Ramaswamy (1998) do not consider variations in width and shape of the used distribution. This is a rather strong simplification (especially having the non-linear hygroscopic growth in mind) in comparison to findings of Quaas (2012) that suggest a change of the width of a uni- form PDF from about $\pm 20 \%$ at the surface to about $\pm 65 \%$ in the middle troposphere.

In this study, we implement a stochastic parameterization of subgrid-scale variability of clear-sky relative humidity $\mathrm{RH}_{\mathrm{cls}}$ into the global aerosol-climate model of the Max Planck Institute for Meteorology (MPI-M) ECHAM6HAM2 (Zhang et al., 2012; Stevens et al., 2013). For this, we use a uniform PDF that reproduces the subsaturated part of the cloud cover scheme from Sundqvist et al. (1989) that is used by ECHAM6 (Stevens et al., 2013). The width of the PDF from the cloud cover scheme is a function of height (Quaas, 2012; Rosch et al., 2015). Hence, our parameterization inherits this feature. ECHAM6-HAM2 until now used the grid-box mean clear-sky relative humidity $\overline{\mathrm{RH}}_{\mathrm{cls}}$ to calculate hygroscopic growth (Zhang et al., 2012). Now, rather than using the grid-box mean, the PDF of the subgrid-scale variability in $\mathrm{RH}_{\mathrm{cls}}$ is randomly sampled for each time step, grid cell and height level to compute the growth factor gf (see Sect. 2). Hence, the parameterization complies with the necessity to be consistent and to introduce as few as possible empirical or tunable parameters. For a more elaborate discussion on the topic in the literature, we refer to Arakawa (2004). Furthermore, hygroscopic growth is computed in ECHAM6HAM2 for all hygroscopic aerosol constituents that are incorporated in the model. Therefore, the effect of subgrid-scale variability in $\mathrm{RH}_{\mathrm{cls}}$ on hygroscopic growth is included for all hygroscopic aerosol particles in the model.

A very similar method of subgrid-scale variability in humidity is, for example, applied on the convective scheme of the European Centre for Medium-Range Weather Forecasts (ECMWF) ensemble prediction system by Tompkins and Berner (2008). They show that their new stochastic convective scheme generally improves the skill of the operational system for most variables in the short to medium range in the mid-latitudes. More generally, we want to emphasize that stochastic parameterizations are not only a method to estimate uncertainties but also lead to a better representation of the mean state of the atmosphere. This was recently summarized in Berner et al. (2016).

In Sect. 2 of this article we describe the aerosol module HAM2 in more detail and introduce our stochastic parameterization of clear-sky relative humidity. Then, in Sect. 3 we investigate how the new parameterization changes optical and radiative properties of the atmosphere. Afterwards, the results are discussed in Sect. 4. Finally, this study is summarized with an outlook for further research in Sect. 5 .

\section{Methods}

\subsection{Aerosol module HAM2}

In this section, we briefly describe the aspects of the microphysical aerosol module HAM2 (Zhang et al., 2012) that are relevant for this study. The micro-physical aerosol module 
HAM2 is the successor of its first version that was introduced by Stier et al. (2005). HAM2 is built as an extension of the atmospheric GCM ECHAM6 (Stevens et al., 2013). It incorporates the following aerosol components: sulfate $\left(\mathrm{SO}_{4}\right)$, black carbon (BC), organic carbon (OC), sea salt (SS) and mineral dust (DU). The module predicts the evolution of the aerosol population based on 7 log-normal modes (4 soluble, $\mathrm{S}$, and 3 insoluble, I) that describe the size distribution of atmospheric aerosols. The modes are divided into Nucleation $(\mathrm{N}, r<0.005 \mu \mathrm{m})$, Aitken $(\mathrm{K}, 0.005<r<0.05 \mu \mathrm{m})$, Accumulation (A, $0.05<r<0.5 \mu \mathrm{m})$ and Coarse $(\mathrm{C}, r>0.5 \mu \mathrm{m})$ and are abbreviated in the following such as CS for soluble Coarse mode. The main soluble aerosol constituents are $\mathrm{SS}, \mathrm{SO}_{4}$ and OC. DU and $\mathrm{BC}$ are considered as insoluble on emission. However, insoluble aerosols can become soluble if they merge with soluble particles due to internal mixing by ageing processes such as condensation and coagulation (Vignati et al., 2004).

Aerosol radiative properties are calculated for 24 spectral bands for shortwave and 16 bands for longwave radiation using Mie theory by applying the algorithm suggested by Toon and Ackerman (1981). The model uses the volume-weighted average refractive indices for internally mixed aerosols where aerosol water is included (Stier et al., 2005; Ghan and Zaveri, 2007). The effective complex radiative indices and the Mie size parameter are then used for the aerosol radiative properties, namely extinction cross section, single scattering albedo and asymmetry parameter in the radiation scheme. For version 2 of the aerosol module, the refractive indices for black carbon were updated with values from Bond and Bergstrom (2006) that led to a reduction of the negative bias due to aerosol absorption enhancement (Stier et al., 2007). In contrast to Jacobson (2012) and Bond et al. (2013), HAM2 does not include a very strong absorption enhancement for absorbing particles inside clouds. It should be noted that the hypothesis of Jacobson (2012) is very controversial and not supported by most other studies (e.g. Twohy et al., 1989; Chýlek et al., 1996; Liu et al., 2002).

\subsection{Hygroscopic growth in HAM2}

Soluble particles can grow in size due to the attraction of water. This hygroscopic growth can be described by the growth factor gf $=r_{\text {wet }} / r_{\text {dry }}$, where $r_{\text {wet }}$ and $r_{\text {dry }}$ are the wet and dry radius of an aerosol particle, respectively. Petters and Kreidenweis (2007) introduced the $\kappa$-Köhler theory to calculate the growth factor as a function of relative humidity and temperature

$\frac{\mathrm{RH}}{\exp \left(\frac{A_{\mathrm{K}}(T)}{D_{\text {dry }} \mathrm{gf}}\right)}=\frac{\mathrm{gf}^{3}-1}{\mathrm{gf}^{3}-(1-\kappa)}$,

where $\mathrm{RH}$ is the ambient relative humidity, $D_{\text {dry }}$ the dry diameter, $A_{\mathrm{K}}$ the temperature-dependent parameter of the
Table 1. $\kappa$ values as used in HAM2 from Zhang et al. (2012). The $\kappa$ value for sulfate in HAM2 is in the range of the observed value for Ammonium sulfate (Petters and Kreidenweis, 2007). Furthermore, HAM2 does not include nitrate in its current set-up.

\begin{tabular}{lr}
\hline Compound & $\kappa$ \\
\hline Sulfate & 0.60 \\
Sea salt & 1.12 \\
Primary organic aerosol & 0.06 \\
Secondary organic aerosol & $0.022-0.070$ \\
Black carbon & 0 \\
Mineral dust & 0 \\
Nitrate & - \\
\hline
\end{tabular}

Kelvin (curvature) effect and $\kappa$ the hygroscopicity. A $\kappa$ value of 0 describes completely hydrophobic aerosols, whereas $\kappa$ values greater than 0.5 describe very hygroscopic aerosols. Aerosol constituents with very high $\kappa$ values in HAM2 are sulfate and sea salt (see Table 1). Note that the $\kappa$ value for sulfate in HAM2 is in the range of the observed value for ammonium sulfate (0.33-0.72; Petters and Kreidenweis, 2007). Furthermore, HAM2 does not include nitrate in its current set-up. The hygroscopicity of internally mixed aerosols is determined by calculating the volume-weighted average of the $\kappa$ values form each soluble compound. In Eq. (1) gf is a strictly monotonically increasing, non-linear function with positive curvature for $\mathrm{RH} \in[0,1]$.

ECHAM6-HAM2 uses the grid-box mean clear-sky relative humidity $\overline{\mathrm{RH}}_{\text {cls }}$ in Eq. (1) to calculate the hygroscopic growth for each aerosol mode. $\overline{\mathrm{RH}}_{\mathrm{cls}}$ is chosen, instead of grid-box mean relative humidity $\overline{\mathrm{RH}}$, because $\overline{\mathrm{RH}}_{\mathrm{cls}}$ is a better estimate for the relative humidity in the cloud-free part of a grid cell than $\overline{\mathrm{RH}}$ and cloud processing and cloud radiative effects are dominant in the cloudy part of a grid box as reasoned in Stier et al. (2005) for ECHAM5-HAM1. This means that since the aerosol-radiation interactions have a small effect compared to the cloud reflectivity in the cloudy part of a grid cell, swelling is only approximately treated in the cloudy part. $\overline{\mathrm{RH}}_{\mathrm{cls}}$ is diagnosed from predicted $\overline{\mathrm{RH}}$. For this, saturation is assumed in clouds $(\mathrm{RH}=1)$. When the grid box is cloud free $(f=0)$ or partly cloudy $(0<f<1)$, clear-sky relative humidity is computed by $\overline{\mathrm{RH}}_{\mathrm{cls}}=(\overline{\mathrm{RH}}-f) /(1-$ $f$ ), where $f$ is the fractional cloud cover. For overcast grid boxes $(f=1)$, the clear-sky relative humidity is set to saturation as well $\left(\overline{\mathrm{RH}}_{\mathrm{cls}}=1\right)$. Using the $\overline{\mathrm{RH}}_{\mathrm{cls}}$ in Eq. (1) implies that no subgrid-scale variability in $\mathrm{RH}_{\mathrm{cls}}$ is used beyond the information supplied by the fractional cloud cover.

\subsection{Stochastic parameterization for the subgrid-scale variability in clear-sky relative humidity}

In the ECHAM model, subgrid-scale variability in specific humidity is already used for the prediction of fractional cloud cover (Stevens et al., 2013). The cloud scheme assumes a 


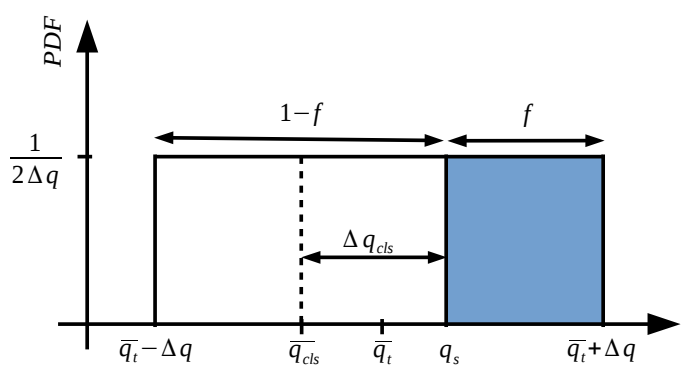

(a)

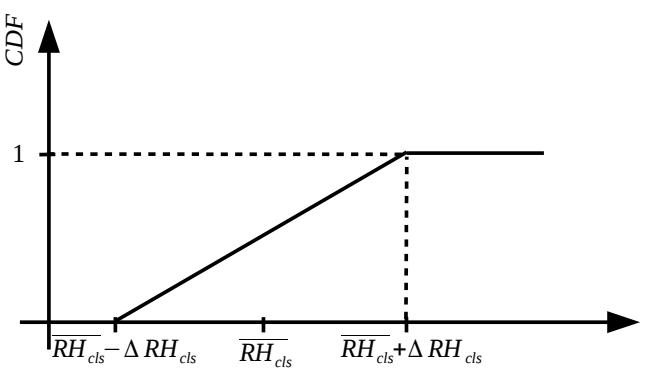

(b)

Figure 1. (a) Scheme for predicting fractional cloud cover, $f$, with a uniform PDF for the total-water $q_{\mathrm{t}}$. The blue area indicates the fraction of a grid cell which is covered by clouds. $\Delta \mathrm{RH}_{\mathrm{cls}}$ is set to $\Delta q / q_{\mathrm{s}}=1-\mathrm{RH}_{\text {crit }}$ for a PDF around $\overline{\mathrm{RH}}_{\mathrm{cls}}$ if no fractional cloud cover is present (not depicted) or set to $\left(q_{\mathrm{s}}-q_{\mathrm{cls}}\right) / q_{\mathrm{s}}=1-\overline{\mathrm{RH}}_{\mathrm{cls}}$ if fractional cloud cover is present (in the figure shown in terms of specific humidity). (b) Cumulative distribution function (CDF) for a uniform PDF around $\overline{\mathrm{RH}}_{\mathrm{cls}}$. By the inversion of the CDF and with a random number $a \in[0,1]$ (see Eq. 6), a value between $\mathrm{RH}_{\mathrm{cls}}-\Delta \mathrm{RH}_{\mathrm{cls}}$ and $\mathrm{RH}_{\mathrm{cls}}+\Delta \mathrm{RH}_{\mathrm{cls}}$ is sampled and used as the argument for the hygroscopic growth.

uniform PDF as proposed by Sundqvist et al. (1989) for the horizontal subgrid-scale variability of total-water $q_{\mathrm{t}}$ between $\bar{q}_{\mathrm{t}}-\Delta q$ and $\bar{q}_{\mathrm{t}}+\Delta q$, where $\Delta q=\gamma q_{\mathrm{s}}$ (see Fig. 1a). Variable $\bar{q}_{\mathrm{t}}$ is the model-predicted grid-box mean total-water specific humidity and $q_{\mathrm{s}}$ the saturation specific humidity computed from the predicted grid-box mean temperature. The scaling parameter $\gamma$ is varying in the vertical but otherwise assumed to be constant in space and time. It can be calculated by $\gamma=1-\mathrm{RH}_{\text {crit }}$, where $\mathrm{RH}_{\text {crit }}$ is the critical relative humidity that is a function of height (Quaas, 2012; Rosch et al., 2015). Fractional cloud cover occurs if the grid-box mean relative humidity $\overline{\mathrm{RH}}$ exceeds the critical relative humidity. In ECHAM6-HAM2, $\mathrm{RH}_{\text {crit }}$ is parameterized by

$\mathrm{RH}_{\text {crit }}(p)=c_{\mathrm{t}}+\left(c_{\mathrm{s}}-c_{\mathrm{t}}\right) \exp \left[1-\left(\frac{p_{\mathrm{s}}}{p}\right)^{n_{x}}\right]$,

with $p$ the ambient pressure and $p_{\mathrm{s}}$ the surface pressure. Furthermore, $c_{\mathrm{t}}=0.7$ and $c_{\mathrm{s}}=0.9$ are the critical relative humidity values at the top of the atmosphere (TOA) and the surface, respectively, and $n_{x}=4$. The given values for $c_{\mathrm{t}}$, $c_{\mathrm{s}}$ and $n_{x}$ are the same as in the in the cloud cover scheme of ECHAM6 in the standard set-up. Note that satellite observations analysed by Quaas (2012) suggest a considerably stronger vertical change with $c_{\mathrm{t}}=0.34$ in less stable regions and $c_{\mathrm{t}}=0.37$. However, we keep the values for $c_{\mathrm{t}}, c_{\mathrm{s}}$ and $n_{x}$ as in the standard set-up to ensure the comparability with older studies. While the formulation of $\mathrm{RH}_{\text {crit }}$ is specific to the ECHAM6 model, the cloud cover scheme from Sundqvist et al. (1989) has also been applied in other global models. Furthermore, the Tiedtke (1993) cloud cover scheme which is, for example, used in the Geophysical Fluid Dynamics Laboratory (GFDL) atmosphere model AM3 (Donner et al., 2011) assumes a uniform PDF of total water as well.

Several global atmosphere models including ECHAM6HAM2 already make assumptions to account for the subgridscale variability in other atmospheric variables, e.g. for vertical velocity when computing droplet activation rates (Ghan et al., 1997; Lohmann et al., 2007; Golaz et al., 2011). However, subgrid-scale variability in $\mathrm{RH}$ or $\mathrm{RH}_{\mathrm{cls}}$ is not taken into account when computing hygroscopic growth of interstitial aerosols except in some studies that made strong simplifications regarding the shape and variation in the used PDF as explained in the introduction (Haywood et al., 1997; Haywood and Ramaswamy, 1998).

For our stochastic parameterization of subgrid-scale variability in $\mathrm{RH}_{\mathrm{cls}}$, we use the subsaturated part of the $q_{\mathrm{t}^{-}}$ PDF from the cloud cover scheme in not-overcast cases (see Fig. 1a). This diagnosed PDF is transformed into a $\mathrm{RH}_{\mathrm{cls}^{-}}{ }^{-}$ PDF dividing it by $q_{\mathrm{s}}$. Afterwards, it is sampled for the stochastic parameterization of subgrid-scale variability in $\mathrm{RH}_{\mathrm{cls}}$. The width of the $q_{\mathrm{t}} \mathrm{PDF}$ in the cloud cover scheme is

$2 \Delta q=2 \gamma q_{\mathrm{s}}=2 \cdot\left(1-\mathrm{RH}_{\text {crit }}\right) q_{\mathrm{s}}$.

Dividing Eq. (3) by $q_{\mathrm{s}}$ yields the width of the corresponding RH-PDF. For cloud-free grid boxes this RH-PDF is equivalent to the $\mathrm{RH}_{\mathrm{cls}}-\mathrm{PDF}$. In this case, its width is

$2 \Delta \mathrm{RH}_{\mathrm{cls}}=2 \frac{\Delta q}{q_{\mathrm{s}}}=2 \cdot\left(1-\mathrm{RH}_{\mathrm{crit}}\right)$.

$\mathrm{RH}_{\text {crit }}$ is computed by Eq. (2). However, when fractional cloud cover is present $\Delta \mathrm{RH}_{\mathrm{cls}}$ has to be adjusted to

$\Delta \mathrm{RH}_{\mathrm{cls}}=\frac{q_{\mathrm{s}}-q_{\mathrm{cls}}}{q_{\mathrm{s}}}=1-\overline{\mathrm{RH}}_{\mathrm{cls}}$

so that the variation in $\mathrm{RH}_{\mathrm{cls}}$ occurs in the subsaturated part of the cloud cover PDF (see Fig. 1a).

Afterwards, instead of using $\overline{\mathrm{RH}}_{\mathrm{cls}}$ as input for the calculation of the gf, a stochastic value for clear-sky relative humidity, $\mathrm{RH}_{\mathrm{cls} \text {, new }}$, from the inversion of the cumulative distribution function (CDF) is drawn (see Fig. 1b). For this, a random number, $a \in[0,1]$, is generated and inserted into the following equation:

$\mathrm{RH}_{\mathrm{cls}, \text { new }}=\overline{\mathrm{RH}}_{\mathrm{cls}}+\Delta \mathrm{RH}_{\mathrm{cls}}(2 a-1)$. 
Note that the integration of the model is not fully deterministic in the current setting. If one preferred a deterministic model, one could configure the random number generator such that in each integration the same random numbers are generated.

\subsection{Model settings and postprocessing}

ECHAM-HAM2 is run with a resolution of T63L31. For aerosol emissions, the AEROCOM II data for 1850 for preindustrial (PI) and for 2000 for present-day (PD) simulations are used (Lamarque et al., 2010; see Data availability). Climatological sea surface temperature (SST) and sea ice distributions are prescribed. Ten-year free-running (no nudging) model simulations starting on 1 January 2000 are performed with PI and PD aerosol emissions, both with and without the new parameterization. The total effective radiative forcing (ERF) by anthropogenic aerosols, ERFaer, is computed by

$\mathrm{ERFaer}=\left(\mathrm{SW}_{\text {net }}+\mathrm{LW}_{\text {net }}\right)_{\mathrm{PD}}-\left(\mathrm{SW}_{\text {net }}+\mathrm{LW}_{\text {net }}\right)_{\mathrm{PI}}$,

where the short and longwave radiative fluxes, SW and LW, are at the TOA. The radiative forcing due to aerosolradiation interactions, RFari, is computed as suggested by Ghan (2013):

$\mathrm{RFari}=\left(\mathrm{SW}_{\text {net }}-\mathrm{SW}_{\text {net,clean }}\right)_{\mathrm{PD}}-\left(\mathrm{SW}_{\text {net }}-\mathrm{SW}_{\text {net, clean }}\right)_{\mathrm{PI}}$.

Again, radiative fluxes are at TOA. The subscript "clean" indicates the results of the radiative transfer equation for an atmosphere with no aerosols.

To depict changes in hygroscopic growth we define the squared ratio

$\beta=\left(\frac{\mathrm{gf}_{\text {stoch }}}{\mathrm{gf}_{\text {control }}}\right)^{2}$,

where $\mathrm{gf}_{\text {stoch }}$ and $\mathrm{gf}_{\text {control }}$ account for the growth factor in the model run with the stochastic parameterization and the control model run, respectively. The squared ratio scales with the effective extinction cross section and therefore describes the influence on AOD.

Satellite retrievals of AOD from the Moderate Resolution Imaging Spectroradiometer (MODIS) platform Aqua (Levy et al., 2013) from the period between August 2002 and December 2010 are used to evaluate the results of implementing subgrid-scale variability in $\mathrm{RH}_{\mathrm{cls}}$ into the model. The temporal mean values of AOD measurements ( $\left.\overline{\mathrm{AOD}}_{\mathrm{MODIS}}\right)$ for the entire time span (August 2002-December 2010) are compared to the temporal means (January 2000-December 2009) of the model data $\left(\overline{\mathrm{AOD}}_{\text {control }}, \overline{\mathrm{AOD}}_{\text {stoch }}\right)$.

\section{Results}

In the following, results from PD simulations, if not specified differently, are presented. We compute uncertainties for a $95 \%$ confidence interval on the basis of yearly mean values from the temporal variability. In these differences, uncertainties are added in quadrature.

In Fig. 2a the global mean profiles of $\beta$ are shown for all soluble aerosol modes. Hygroscopic growth of aerosols is in general enhanced due to the implementation of a subgridscale variability in $\mathrm{RH}_{\mathrm{cls}}$. We find that the effect is stronger for aerosol particles with a large particle radius. Thus, the effect is strongest for particles from the CS mode (red line in Fig. 2a) and weakest for particles from the NS mode (black line in Fig. 2a). Moreover, the effect on hygroscopic growth has a maximum between 700 and $600 \mathrm{hPa}$ for each aerosol mode.

The global mean AOD increases by $0.009 \pm 0.002$ $(\sim 7.8 \%)$. The response in AOD is weaker in simulations with PI emissions with a global mean difference of $0.006 \pm$ $0.002(\sim 6.0 \%)$. Figure 3 a shows that the AOD increased especially in lower latitudes with a mean of about 0.013 in the tropics. Furthermore, the figure reveals that the AOD of diagnosed aerosol water (WAT) dominates the change in total AOD and not the change in dry matter of $\mathrm{SS}_{\text {or }} \mathrm{SO}_{4}$. Figure $3 \mathrm{~b}$ shows the zonal mean AOD values from the model runs with and without the stochastic parameterization and from satellite measurements of MODIS-Aqua. Changes due to the new parameterization are small in comparison to the general difference between modelled and measured AOD. The absorption aerosol optical depth (AAOD) increased by $0.12 \pm 0.04 \times 10^{-3}(\sim 4.7 \%)$, mainly due to an increase in AAOD by $\mathrm{BC}$ of about $0.11 \times 10^{-3}$. However, note that in absolute terms the change in AOD is nearly 2 orders of magnitude greater than the change in AAOD.

Furthermore, the implementation of the new parameterization enhanced the ratio of scattering efficiency to total extinction efficiency, $\omega$, for the $\mathrm{CS}$, AS and KS aerosol modes with a maximum for the KS mode $(2.6 \%)$. The effective extinction cross section, $\sigma$, increases for the $\mathrm{CS}$, AS and KS aerosol modes as well. The strongest change is visible for the KS mode with a change by $15.1 \%$. Note that no output for $\omega$ and $\sigma$ is generated by the model for NS mode. Finally, the Ångström exponent for wet particles, $\alpha$, changes by $-0.8 \times 10^{-3} \pm 11.5 \times 10^{-3}(-0.11 \%)$. The total cloud cover decreased by $-0.08 \pm 0.14 \%$ in PD simulations. In contrast, it increased by $0.17 \pm 0.14$ in PI simulations. The global mean profile of cloud cover $f$ in Fig. 4 reveals a slight increase in cloud cover between 700 and $900 \mathrm{hPa}$ for PD simulations, whereas it mainly decreased below and above this layer. However, in PI runs $f$ increased for most parts of the atmosphere with a very little decrease at around $600 \mathrm{hPa}$.

In the following, solar and thermal clear-sky radiation represent the idealized solar and thermal irradiance that would arise from an atmosphere if clouds were absent, whereas all- 


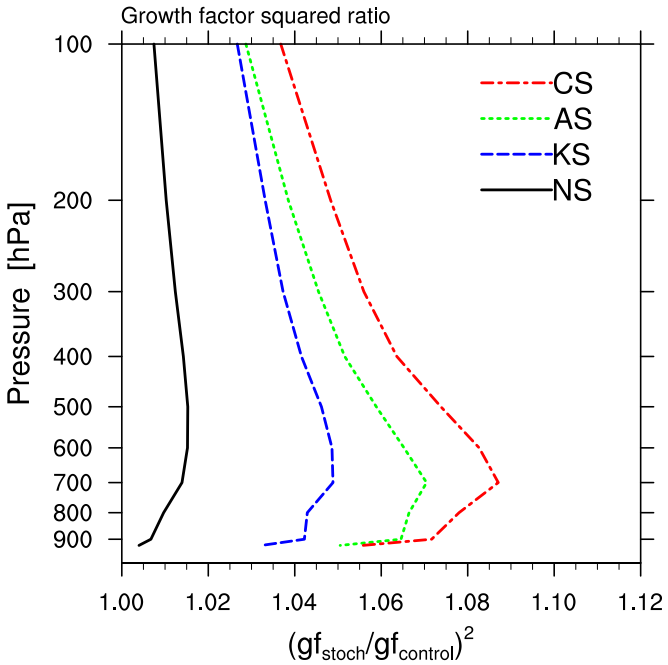

(a)

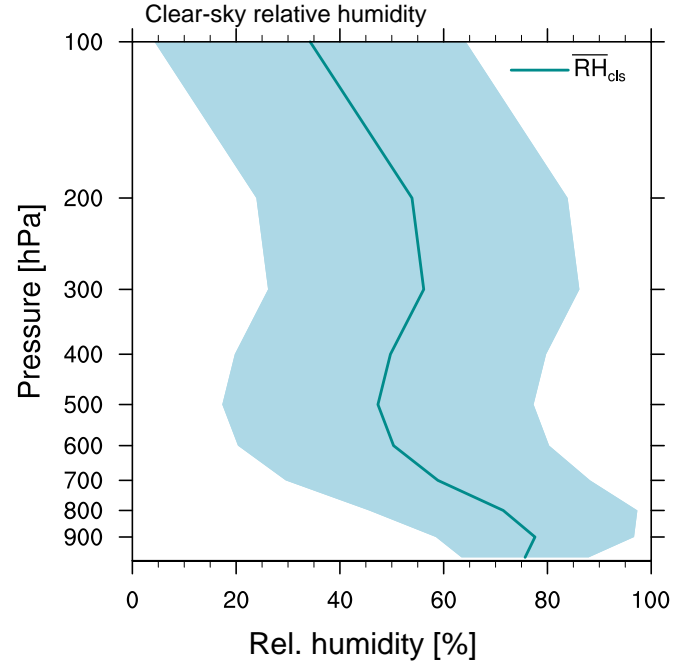

(b)

Figure 2. (a) Profile of the global mean of the squared ratio of the growth factor between the run with the stochastic parameterization of hygroscopic growth, $\mathrm{gf}_{\text {stoch }}$, and the control run, $\mathrm{gf}_{\text {control }}$. CS is the soluble Coarse aerosol mode (red). AS the soluble Accumulation (green), KS the soluble Aitken (blue) and NS the soluble Nucleation aerosol mode (black). (b) Profile of global mean clear-sky relative humidity (dark blue line) with its corresponding range of subgrid-scale variability (light blue area).

sky stands for the irradiance that takes the effect of clouds into account. The net clear-sky solar radiation $\mathrm{SW}_{\text {net,cls }}$ decreases by $-0.22 \pm 0.07 \mathrm{Wm}^{-2}$. In addition, the net all-sky solar radiation $\mathrm{SW}_{\text {net }}$ changes by $-0.34 \pm 0.22 \mathrm{~W} \mathrm{~m}^{-2}$. For PI emissions, the effect on $\mathrm{SW}_{\text {net,cls }}$ is with a change of $-0.13 \pm 0.06 \mathrm{~W} \mathrm{~m}^{-2}$, as expected, smaller than for PD emissions. In contrast, a stronger effect in PI runs than in PD runs is visible for $\mathrm{SW}_{\text {net }}\left(-0.47 \pm 0.19 \mathrm{~W} \mathrm{~m}^{-2}\right)$. Responses in the thermal radiation (positive downward) are small. The clear-sky thermal radiation $\mathrm{LW}_{\text {net,cls }}$ has a slight positive tendency with a mean value of $0.04 \pm 0.09 \mathrm{~W} \mathrm{~m}^{-2}$. Similar to solar radiation, the all-sky thermal radiation $\mathrm{LW}_{\text {net }}$ changes more than the clear-sky radiation with a global mean of $0.06 \pm 0.14 \mathrm{~W} \mathrm{~m}^{-2}$.

The comparison of 10-year model runs with $\mathrm{PD}$ and PI aerosol emissions reveals a change of the RFari from $-0.15 \pm 0.04$ to $-0.19 \pm 0.04 \mathrm{Wm}^{-2}(31 \%)$ in runs without and runs with the new parameterization, respectively. This implies that subgrid-scale variability of $\mathrm{RH}_{\mathrm{cls}}$ enhances the cooling effect of anthropogenic aerosol emissions by aerosol-radiation interactions in climate simulations. It is interesting to note that the RFari increases substantially given the relatively small impact of the revision on present-day TOA balance. This can be attributed to the fact that anthropogenic aerosol is disproportionally hygroscopic. Furthermore, the effect on RFari translates into the ERF of anthropogenic aerosols (ERFaer) that also has a negative tendency $(-0.07 \pm 0.27)$. A summary of the influence of subgrid-scale variability in $\mathrm{RH}_{\mathrm{cls}}$ on optical and radiative variables is given in Table 2.

\section{Discussion}

As for the previous section, we discuss in the following the results from PD simulations, if not specified differently. In model runs with the new parameterization, aerosol particles swell stronger at each height level due to the non-linear nature of hygroscopic growth (see Eq. 1). The positive curvature of this function for $\mathrm{RH}_{\mathrm{cls}} \in[0,1]$ implies that by applying a uniform $\mathrm{PDF}$ on $\mathrm{RH}_{\mathrm{cls}}$ the expected value of $\mathrm{gf}\left(\mathrm{RH}_{\mathrm{cls}}\right)$ is greater than $\mathrm{gf}\left(\overline{\mathrm{RH}}_{\mathrm{cls}}\right)$ with $\overline{\mathrm{RH}}_{\mathrm{cls}}$ being the grid-box mean clear-sky relative humidity.

Effects are stronger for aerosol particles with a larger radius, and thus particles from CS and AS modes. Three reasons can explain the vertical shape of the gf profiles:

1. Clear-sky relative humidity has a decreasing trend with height in the model (see Fig. 2b). The same change in $\Delta \mathrm{RH}_{\mathrm{cls}}$ in a drier environment leads to a smaller change in $\mathrm{gf}$ in a more humid environment (unless saturation is reached) because of the non-linearity of Eq. (1). The effect of the subgrid-scale variability in $\mathrm{RH}_{\mathrm{cls}}$ on gf is therefore stronger in a more humid environment.

2. Very hygroscopic aerosol particles are more sensitive to changes in relative humidity and larger particles tend to become deposited by impaction and sedimentation more easily. The main hygroscopic aerosol types are sulfate and sea salt, where sea salt $(\kappa=1.12)$ is more hygroscopic than sulfate $(\kappa=0.6)$. Sea-salt particles are emitted at the surface of the ocean. Due to their high $\kappa$ value, sea-salt particles grow strongly, are deposited easily and can not reach high altitudes. This is indi- 
Table 2. Changes in global mean values of optical and radiative variables due to the implementation of subgrid-scale variability in $\mathrm{RH}_{\mathrm{cls}}$ are listed. Uncertainties in the mean value are calculated for a $95 \%$ confidence interval on the basis of yearly mean values from the temporal variability. Uncertainties in differences are added in quadrature. Symbol $\omega$ is the ratio of the scattering efficiency to the total extinction efficiency and $\sigma$ the effective extinction cross section. The indices KS, AS and CS indicate Aitken, Accumulation and Coarse modes, respectively. Symbol $\alpha$ is the wet Angström exponent, $\mathrm{SW}_{\text {net }}$ the net shortwave radiation and with index $\mathrm{SW}_{\text {net,cls }}$ the net shortwave radiation in the clear-sky part. With the same meaning for the indices LW is the longwave radiation. TCC is the total cloud cover. Results are presented for present-day and pre-industrial emissions.

\begin{tabular}{|c|c|c|c|c|}
\hline Variable & Stoch & Control & Difference & Relative deviation \\
\hline RFari $\left(\mathrm{W} \mathrm{m}^{-2}\right)$ & $-0.19 \pm 0.04$ & $-0.15 \pm 0.04$ & $-0.04 \pm 0.06$ & $31 \%$ \\
\hline \multirow[t]{2}{*}{ ERFaer $\left(\mathrm{W} \mathrm{m}^{-2}\right)$} & $-1.52 \pm 0.16$ & $-1.45 \pm 0.21$ & $-0.07 \pm 0.27$ & $5 \%$ \\
\hline & \multicolumn{2}{|c|}{ Present-day } & \multicolumn{2}{|c|}{ Pre-industrial } \\
\hline Variable & Difference & Relative deviation & Difference & Relative deviation \\
\hline $\mathrm{SW}_{\text {net }}\left(\mathrm{Wm}^{-2}\right)$ & $-0.34 \pm 0.22$ & $-0.15 \%$ & $-0.47 \pm 0.19$ & $-0.20 \%$ \\
\hline $\mathrm{SW}_{\text {net, }, \mathrm{cls}}\left(\mathrm{Wm}^{-2}\right)$ & $-0.22 \pm 0.07$ & $-0.08 \%$ & $-0.13 \pm 0.06$ & $-0.05 \%$ \\
\hline $\mathrm{LW}_{\text {net }}\left(\mathrm{W} \mathrm{m}^{-2}\right)$ & $0.06 \pm 0.14$ & $0.03 \%$ & $0.26 \pm 0.17$ & $0.10 \%$ \\
\hline $\mathrm{LW}_{\text {net, }, \mathrm{cls}}\left(\mathrm{W} \mathrm{m}^{-2}\right)$ & $0.04 \pm 0.09$ & $0.02 \%$ & $0.11 \pm 0.10$ & $0.04 \%$ \\
\hline $\operatorname{TCC}(\%)$ & $-0.08 \pm 0.14$ & $-0.13 \%$ & $0.17 \pm 0.14$ & $0.26 \%$ \\
\hline AOD & $0.009 \pm 0.002$ & $7.8 \%$ & $0.006 \pm 0.002$ & $6.0 \%$ \\
\hline $\mathrm{AOD}_{\mathrm{WAT}}$ & $0.008 \pm 0.001$ & $9.5 \%$ & $0.005 \pm 0.001$ & $7.8 \%$ \\
\hline AAOD & $(0.12 \pm 0.04) \times 10^{-3}$ & $4.7 \%$ & $(0.04 \pm 0.03) \times 10^{-3}$ & $2.7 \%$ \\
\hline $\mathrm{AAOD}_{\mathrm{BC}}$ & $(0.11 \pm 0.03) \times 10^{-3}$ & $5.1 \%$ & $(0.03 \pm 0.01) \times 10^{-3}$ & $3.4 \%$ \\
\hline$\omega_{\mathrm{KS}}$ & $0.015 \pm 0.003$ & $2.64 \%$ & $0.014 \pm 0.005$ & $2.42 \%$ \\
\hline$\omega_{\mathrm{AS}}$ & $(1.1 \pm 0.4) \times 10^{-3}$ & $0.11 \%$ & $(0.9 \pm 0.6) \times 10^{-3}$ & $0.10 \%$ \\
\hline$\omega_{\mathrm{CS}}$ & $(0.03 \pm 0.05) \times 10^{-3}$ & $0.003 \%$ & $(0.05 \pm 0.15) \times 10^{-3}$ & $0.005 \%$ \\
\hline$\sigma_{\mathrm{KS}}$ & $(9.7 \pm 1.0) \times 10^{-18}$ & $15.1 \%$ & $(8.0 \pm 1.1) \times 10^{-18}$ & $14.3 \%$ \\
\hline$\sigma_{\mathrm{AS}}$ & $(20.8 \pm 6.9) \times 10^{-15}$ & $4.5 \%$ & $(22.7 \pm 7.2) \times 10^{-15}$ & $4.8 \%$ \\
\hline$\sigma_{\mathrm{CS}}$ & $\left(0.69 \pm 0.07 \times 10^{-12}\right.$ & $3.9 \%$ & $(0.71 \pm 0.07) \times 10^{-12}$ & $4.0 \%$ \\
\hline$\alpha$ & $(-0.8 \pm 11.5) \times 10^{-3}$ & $-0.11 \%$ & $(6.4 \pm 13.8) \times 10^{-3}$ & $0.94 \%$ \\
\hline
\end{tabular}

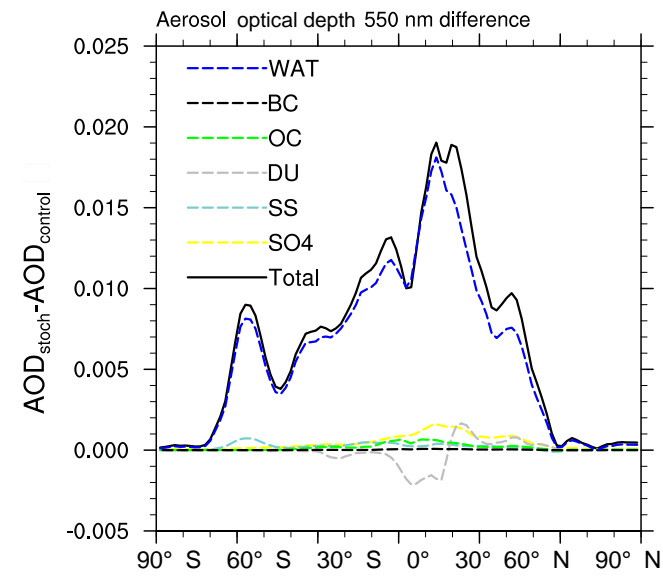

(a)

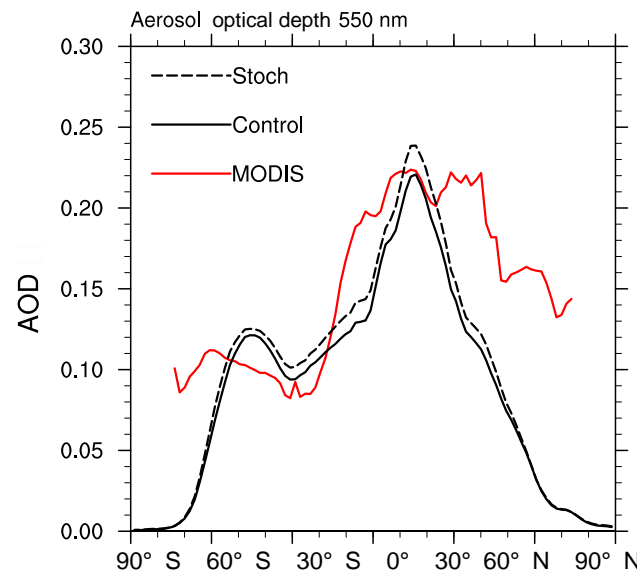

(b)

Figure 3. (a) Difference in temporally and zonally averaged AOD between the stochastic variation and the control run in AOD for different aerosol constituents. AOD from diagnosed aerosol water (WAT, blue) dominates the changes. (b) Temporally and zonally averaged AOD from the control (solid) and stochastic (dashed) model runs (black, January 2000-December 2009), and Moderate Resolution Imaging Spectroradiometer (Levy et al., 2013) Aqua satellite data (red, August 2002-December 2010) is shown. Two discrepancies arise, namely (i) the fact that the model diagnoses clear-sky AOD also in overcast grid cells, with a relative humidity of $\mathrm{RH}=1$ in these cases, which are dismissed in the MODIS retrieval and (ii) the point that MODIS uses a conservative cloud masking, i.e. excludes pixels near cloud edges, whereas the model uses all clear-sky pixels. 


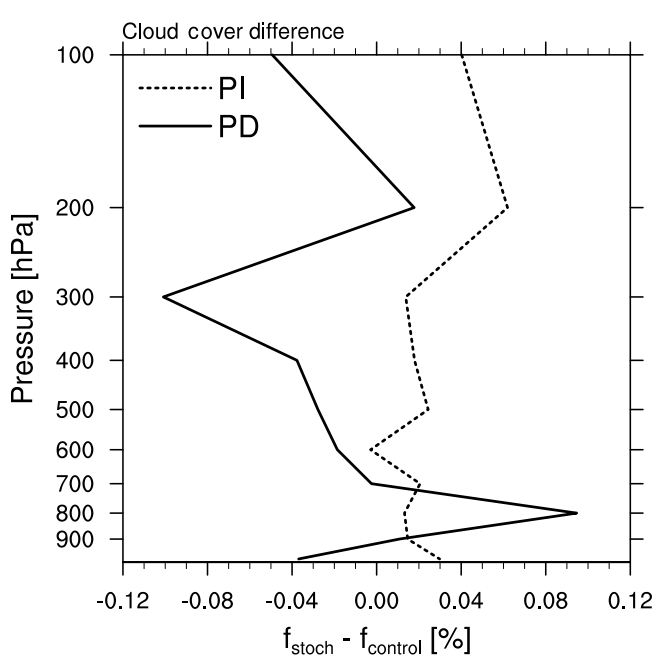

(a)

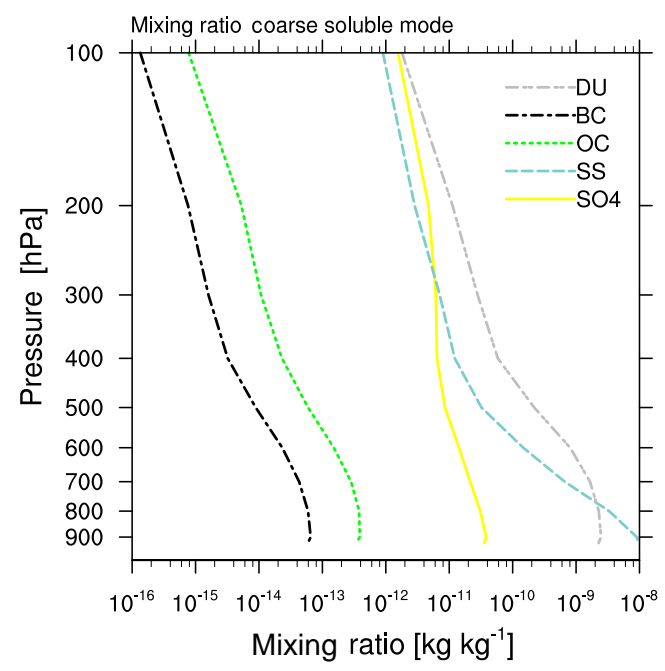

(b)

Figure 4. (a) Difference in cloud cover, $f$, due to the implementation of subgrid-scale variability in $\mathrm{RH}_{\mathrm{cls}}$ for PI (dashed) and PD (solid) simulations. (b) Global mean profile of mass mixing ratio for various aerosol compounds from the CS mode.

cated in Fig. 4b which shows that the mixing ratio of sea salt decreases noticeably stronger with height than other aerosol compounds. Hence, the aerosol composition of the atmosphere shifts towards less hygroscopic components (smaller $\kappa$ values) with height and the effect of perturbing relative humidity on hygroscopic growth becomes weaker with smaller $\kappa$ values. This is supported by the study of Pringle et al. (2010) that examines the global distribution of $\kappa$ using the ECHAM/MESSy Atmospheric Chemistry (EMAC) model. They find that especially at marine sites $\kappa$ values decrease with height, whereas at continental sites $\kappa$ tends to be more constant with height.

Reasons 1 and 2 can only explain a decreasing trend of $\beta$ with height but not the maxima of the $\beta$ profiles between 600 and $700 \mathrm{hPa}$.

3. The critical relative humidity determines the width of the PDF which is used to vary $\mathrm{RH}_{\text {cls }}$ stochastically. The width $2 \Delta \mathrm{RH}_{\mathrm{cls}}$ of the PDF is calculated by $\Delta \mathrm{RH}_{\mathrm{cls}}=$ $1-\mathrm{RH}_{\text {crit }}$ as described in Sect. 2. But $\mathrm{RH}_{\text {crit }}$ is a function of height (see Eq. 2). It decreases from the surface to $600 \mathrm{hPa}$ from 0.9 to close to 0.7. For higher altitudes, it is nearly constant and converges slowly towards 0.7 (see Fig. 2b). This in fact means that the width of the PDF increases with height from the surface to $600 \mathrm{hPa}$. Then, it is almost constant. The positive curvature of Eq. (1) implies that the wider the PDF is the stronger the mean hygroscopic growth. The increasing width of the PDF explains why $\beta$ becomes greater with height until $600 \mathrm{hPa}$. Above, effects 1 and 2 are dominant and $\beta$ decreases again.
The AOD, the effective extinction cross section, $\sigma$, and the ratio of scattering efficiency to total extinction efficiency, $\omega$, are enhanced because of the increase in the geometrical radius of the particles. Anthropogenic aerosols that arise in PD simulations are disproportionally hygroscopic. Therefore, hygroscopic aerosols swell stronger due to the new parameterization in PD than in PI simulations and scatter more solar radiation. This leads in turn to a higher AOD in PD than PI runs. The effect of the new parameterization is especially strong for lower latitudes because of the higher abundance of sea salt (not depicted) in these regions. In addition, anthropogenic emissions of sulfate are strong in China, India and over the Arabian Peninsula and contribute to the peak of increased AOD in the northern tropics. Note that ECHAM6HAM2 currently does not simulate nitrate aerosols. The integration of nitrate aerosols will introduce very hygroscopic aerosols into the model that would alter our results. As Fig. 3b demonstrates, little can be said about improved skill of ECHAM-HAM2 to model AOD in respect to AOD satellite retrievals of MODIS-Aqua.

The net clear-sky solar radiation $\mathrm{SW}_{\text {net,cls }}$ decreases $\left(\Delta \mathrm{SW}_{\text {net,cls }}=-0.22 \mathrm{~W} \mathrm{~m}^{-2}\right)$ due to an increased reflection of solar radiation as indicated by an increased $\omega$. However, the effect on the net all-sky solar radiation $\mathrm{SW}_{\text {net }}$ is greater $\left(\Delta \mathrm{SW}_{\text {net }}=-0.34 \mathrm{~W} \mathrm{~m}^{-2}\right)$ than the effect on the net clearsky solar radiation. This is maybe due to the fact that although total cloud cover (TCC) decreased by $-0.08 \%$, cloud cover is slightly enhanced in height levels between about 700 and $900 \mathrm{hPa}$ (see graph for PD in Fig. 4). Hence, more solar radiation is reflected back to space by these clouds.

We proceed with the discussion of differences that arise between PD and PI simulations. The change in $\mathrm{SW}_{\text {net,cls }}$ is stronger for PD than for PI emissions because backscat- 
tering of solar radiation is more enhanced by the new parameterization in PD than in PI simulations because anthropogenic aerosols are disproportionally hygroscopic. In addition, the response of RFari $\left(-0.04 \mathrm{~W} \mathrm{~m}^{-2}, 31 \%\right)$ indicates as well that the parameterization leads to stronger backscattering by aerosols. Unexpectedly, the response in $\mathrm{SW}_{\text {net }}$ is greater in PI runs $\left(\Delta \mathrm{SW}_{\text {net,PI }}=-0.47 \mathrm{~W} \mathrm{~m}^{-2}\right)$ than in PD runs $\left(\Delta \mathrm{SW}_{\text {net, } \mathrm{PD}}=-0.34 \mathrm{~W} \mathrm{~m}^{-2}\right)$. We assume that this might be due to the enhanced total cloud cover in the PI simulations $\left(\triangle T C_{P I}=0.17\right)$, whereas total cloud cover decreased in PD simulations $\left(\Delta \mathrm{TCC}_{\mathrm{PD}}=-0.08\right)$. We ascribe the differences in cloud cover to internal variability. Hence, we suspect that the converse results for $\mathrm{SW}_{\text {net }}$ arise due to internal variability. The stronger increase in cloud cover for the higher troposphere in PI simulations (see Fig. 4) might explain the strong response of $\mathrm{LW}_{\text {net }}$ in PI simulations $\left(\Delta \mathrm{LW}_{\text {net, } \mathrm{PI}}=0.26 \mathrm{~W} \mathrm{~m}^{-2}\right)$. High, thin clouds, namely cirrus clouds, are known to have a positive effect on outgoing longwave radiation (Hartmann et al., 1992; Chen et al., 2000).

\section{Conclusions}

This study proposes a stochastic parameterization of clearsky relative humidity that is consistent with the cloud cover scheme for its application in the aerosol hygroscopic growth parameterization. We investigate its effect on hygroscopic growth of aerosol particles as well as the subsequent changes in optical properties of the atmosphere and the radiative balance of the Earth. The implementation of the new parameterization leads to stronger swelling of aerosol particles (as expected) and therefore increases the AOD $(\sim 7.8 \%)$. Furthermore, the increased AOD causes stronger backscattering of solar radiation under clear-sky conditions $\mathrm{SW}_{\text {net,cls }}$ $(-0.08 \%)$. Most importantly, the revision has a very strong influence on the simulated radiative forcing due to aerosolradiation interaction RFari (31\%). In earlier studies RFari by sulfate increased in GCMs by about $10 \%$ when an idealized distribution for RH was implemented (Haywood and Shine, 1997; Haywood and Ramaswamy, 1998). Further studies found that GCMs underestimate RFari of sulfate when subgrid-scale variability in RH is not taken into account by $73 \%$ in a limited-area model case study (Haywood et al., 1997), by 30 to $80 \%$ in a study that used a cloudresolving model over a tropical ocean and a mid-latitude continental region (Petch, 2001) and by 30 to $40 \%$ in a regional study (Europe and much of the North Atlantic) with a highresolution model (Myhre et al., 2002). Hence, our study is in line with previous studies based on limited-area models. The effect of including RH subgrid variability, however, is bigger than the one found in the early global model study by Haywood and Ramaswamy (1998).

One might be able to further improve the parameterization of subgrid-scale variability in $\mathrm{RH}_{\mathrm{cls}}$ by applying the subsaturated part of the $\beta$-function from the optional Tomp- kins (2002) cloud cover scheme that prognostically treats the total-water variability PDF. Furthermore, Fig. 2 in Quaas (2012) indicates that the critical relative humidity, $\mathrm{RH}_{\text {crit }}$, that defines the width of the introduced $\mathrm{RH}_{\mathrm{cls}} \mathrm{PDF}$ varies horizontally on the same scale as vertically. Therefore, the width of the $\mathrm{RH}_{\mathrm{cls}}-\mathrm{PDF}$ could be extended from just heightdependent to height- and zonal- or even height-, zonal- and meridional-dependent.

Code availability. The code for the subgrid-scale variability in $\mathrm{RH}_{\mathrm{cls}}$ is available upon request from the first author.

Data availability. The ECHAM6-HAM2 model output data used in this study is archived at the Leipzig Institute for Meteorology (LIM) and at the German Climate Computing Center (DKRZ). Data is available upon request from the authors. Satellite data from MODIS-Aqua can be obtained at https://neo.sci.gsfc.nasa.gov/, last access: 28 November 2014. AEROCOM emission data can be downloaded at http://aerocom.met.no/emissions.html, last access: 4 May 2012.

Competing interests. The authors declare that they have no conflict of interest.

Acknowledgements. The ECHAM-HAM model is developed by a consortium composed of ETH Zurich, Max Planck Institut für Meteorologie, Forschungszentrum Jülich, University of Oxford, the Finnish Meteorological Institute and the Leibniz Institute for Tropospheric Research, and managed by the Center for Climate Systems Modeling (C2SM) at ETH Zurich. The MODIS data are from the NASA Goddard Space Flight Center. Funding by the European Research Council in Starting Grant, grant agreement FP7-306284 (QUAERERE) is acknowledged. We thank Steven J. Ghan and one anonymous reviewer for their work reviewing our manuscript.

Edited by: Kostas Tsigaridis

Reviewed by: Steven J. Ghan and one anonymous referee

\section{References}

Arakawa, A.: The Cumulus Parameterization Problem: Past, Present, and Future, J. Climate, 17, 2493-2525, https://doi.org/10.1175/15200442(2004)017<2493:RATCPP>2.0.CO;2, 2004.

Beer, A.: Bestimmung der Absorption des rothen Lichts in farbigen Flüssigkeiten, Ann. Phys.-Berlin, 162, 78-88, 1852.

Berner, J., Achatz, U., Batté, L., Bengtsson, L., Cámara, A. D. L., Christensen, H. M., Colangeli, M., Coleman, D. R. B., Crommelin, D., Dolaptchiev, S. I., Franzke, C. L. E., Friederichs, P., Imkeller, P., Järvinen, H., Juricke, S., Kitsios, V., Lott, F., Lucarini, V., Mahajan, S., Palmer, T. N., Penland, C., Sakradzija, M., von Storch, J.-S., Weisheimer, A., Weniger, M., Williams, 
P. D., and Yano, J.-I.: Stochastic Parameterization: Toward a New View of Weather and Climate Models, B. Am. Meteorol. Soc., 98, 565-588, https://doi.org/10.1175/BAMS-D-15$00268.1,2016$.

Bond, T. C. and Bergstrom, R. W.: Light Absorption by Carbonaceous Particles: An Investigative Review, Aerosol Sci. Tech., 40, 27-67, https://doi.org/10.1080/02786820500421521, 2006.

Bond, T. C., Doherty, S. J., Fahey, D. W., Forster, P. M., Berntsen, T., DeAngelo, B. J., Flanner, M. G., Ghan, S., Kärcher, B., Koch, D., Kinne, S., Kondo, Y., Quinn, P. K., Sarofim, M. C., Schultz, M. G., Schulz, M., Venkataraman, C., Zhang, H., Zhang, S., Bellouin, N., Guttikunda, S. K., Hopke, P. K., Jacobson, M. Z., Kaiser, J. W., Klimont, Z., Lohmann, U., Schwarz, J. P., Shindell, D., Storelvmo, T., Warren, S. G., and Zender, C. S.: Bounding the role of black carbon in the climate system: A scientific assessment, J. Geophys. Res.-Atmos., 118, 5380-5552, https://doi.org/10.1002/jgrd.50171, 2013.

Boucher, O., Randall, D., Artaxo, P., Bretherton, C., Feingold, G., Forster, P., Kerminen, V.-M., Kondo, Y., Liao, H., Lohmann, U., Rasch, P., Satheesh, S. K., Sherwood, S., Stevens, B., and Zhang, X. Y.: Clouds and Aerosols, in: Climate Change 2013: The Physical Science Basis. Contribution of Working Group I to the Fifth Assessment Report of the Intergovernmental Panel on Climate Change, edited by: Stocker, T. F., Qin, D., Plattner, G.-K., Tignor, M., Allen, S. K., Boschung, J., Nauels, A., Xia, Y., Bex, V., and Midgley, P. M., Cambridge University Press, Cambridge, United Kingdom and New York, NY, USA, 2013.

Chen, T., Rossow, W. B., and Zhang, Y.: Radiative Effects of Cloud-Type Variations, J. Climate, 13, 264-286, https://doi.org/10.1175/15200442(2000)013<0264:REOCTV>2.0.CO;2, 2000.

Chýlek, P., Lesins, G. B., Videen, G., Wong, J. G. D., Pinnick, R. G., Ngo, D., and Klett, J. D.: Black carbon and absorption of solar radiation by clouds, J. Geophys. Res., 101, 23365-23371, https://doi.org/10.1029/96JD01901, 1996.

Donner, L. J., Wyman, B. L., Hemler, R. S., Horowitz, L. W., Ming, Y., Zhao, M., Golaz, J.-C., Ginoux, P., Lin, S.-J., Schwarzkopf, D. M., Austin, J., Alaka, G., Cooke, W. F., Delworth, T. L., Freidenreich, S. M., Gordon, C. T., Griffies, S. M., Held, I. M., Hurlin, W. J., Klein, S. A., Knutson, T. R., Langenhorst, A. R., Lee, H.-C., Lin, Y., Magi, B. I., Malyshev, S. L., Milly, P. C. D., Naik, V., Nath, M. J., Pincus, R., Ploshay, J. J., Ramaswamy, V., Seman, C. J., Shevliakova, E., Sirutis, J. J., Stern, W. F., Stouffer, R. J., Wilson, R. J., Winton, M., Wittenberg, A. T., and Zeng, F.: The dynamical core, physical parameterizations, and basic simulation characteristics of the atmospheric component AM3 of the GFDL global coupled model CM3, J. Climate, 24, 3484-3519, https://doi.org/10.1175/2011JCLI3955.1, 2011.

Ghan, S. J.: Technical Note: Estimating aerosol effects on cloud radiative forcing, Atmos. Chem. Phys., 13, 9971-9974, https://doi.org/10.5194/acp-13-9971-2013, 2013.

Ghan, S. J. and Zaveri, R. A.: Parameterization of optical properties for hydrated internally mixed aerosol, J. Geophys. Res., 112, D10201, https://doi.org/10.1029/2006JD007927, 2007.

Ghan, S. J., Leung, L. R., Easter, R. C., and Abdul-Razzak, H.: Prediction of cloud droplet number in a general circulation model, J. Geophys. Res., 102, 21777-21794, 1997.

Ginoux, P.: Atmospheric chemistry: Warming or cooling dust?, Nat. Geosci., 10, 246-248, https://doi.org/10.1038/ngeo2923, 2017.
Golaz, J.-C., Salzmann, M., Donner, L. J., Horowitz, L. W., Ming, Y., and Zhao, M.: Sensitivity of the aerosol indirect effect to subgrid variability in the cloud parameterization of the GFDL Atmosphere General Circulation Model AM3, J. Climate, 24, https://doi.org/10.1175/2010JCLI3945.1, 2011.

Gustafson, W. I., Qian, Y., and Fast, J. D.: Downscaling aerosols and the impact of neglected subgrid processes on direct aerosol radiative forcing for a representative global climate model grid spacing, J. Geophys. Res., 116, D13303, https://doi.org/10.1029/2010JD015480, 2011.

Haarig, M., Ansmann, A., Gasteiger, J., Kandler, K., Althausen, D., Baars, H., Radenz, M., and Farrell, D. A.: Dry versus wet marine particle optical properties: RH dependence of depolarization ratio, backscatter, and extinction from multiwavelength lidar measurements during SALTRACE, Atmos. Chem. Phys., 17, 1419914217, https://doi.org/10.5194/acp-17-14199-2017, 2017.

Hartmann, D. L., Ockert-Bell, M. E., and Michelsen, M. L.: The Effect of Cloud Type on Earth's Energy Balance: Global Analysis, J. Climate, 5, 1281-1304, https://doi.org/10.1175/15200442(1992)005<1281:TEOCTO>2.0.CO;2, 1992.

Haywood, J. M. and Ramaswamy, V.: Global sensitivity studies of the direct radiative forcing due to anthropogenic sulfate and black carbon aerosols, J. Geophys. Res., 103, 6043-6058, https://doi.org/10.1029/97JD03426, 1998.

Haywood, J. M. and Shine, K. P.: Multi-spectral calculations of the direct radiative forcing of tropospheric sulphate and soot aerosols using a column model, Q. J. Roy. Meteor. Soc., 123, 1907-1930, https://doi.org/10.1002/qj.49712354307, 1997.

Haywood, J. M., Ramaswamy, V., and Donner, L. J.: A limitedarea-model case study of the effects of sub-grid scale Variations in relative humidity and cloud upon the direct radiative forcing of sulfate aerosol, Geophys. Res. Lett., 24, 143-146, https://doi.org/10.1029/96GL03812, 1997.

Jacobson, M. Z.: Investigating cloud absorption effects: Global absorption properties of black carbon, tar balls, and soil dust in clouds and aerosols, J. Geophys. Res., 117, D06205, https://doi.org/10.1029/2011JD017218, 2012.

Köhler, H.: The nucleus in and the growth of hygroscopic droplets, T. Faraday Soc., 32, 1152-1161, https://doi.org/10.1039/TF9363201152, 1936.

Lamarque, J.-F., Bond, T. C., Eyring, V., Granier, C., Heil, A., Klimont, Z., Lee, D., Liousse, C., Mieville, A., Owen, B., Schultz, M. G., Shindell, D., Smith, S. J., Stehfest, E., Van Aardenne, J., Cooper, O. R., Kainuma, M., Mahowald, N., McConnell, J. R., Naik, V., Riahi, K., and van Vuuren, D. P.: Historical (1850-2000) gridded anthropogenic and biomass burning emissions of reactive gases and aerosols: methodology and application, Atmos. Chem. Phys., 10, 7017-7039, https://doi.org/10.5194/acp-10-7017-2010, 2010.

Lambert, J. H.: Photometria, sive de Mensura et Gradibus Luminis, Colorum et Umbrae, VE Klett, Augustae Vindelicorum, 1760.

Levy, R. C., Mattoo, S., Munchak, L. A., Remer, L. A., Sayer, A. M., Patadia, F., and Hsu, N. C.: The Collection 6 MODIS aerosol products over land and ocean, Atmos. Meas. Tech., 6, 29893034, https://doi.org/10.5194/amt-6-2989-2013, 2013.

Liu, L., Mishchenko, M. I., Menon, S., Macke, A., and Lacis, A. A.: The effect of black carbon on scattering and absorption of solar radiation by cloud droplets, J. Quant. Spectrosc. Ra., 74, 195204, https://doi.org/10.1016/S0022-4073(01)00232-1, 2002. 
Lohmann, U., Stier, P., Hoose, C., Ferrachat, S., Kloster, S., Roeckner, E., and Zhang, J.: Cloud microphysics and aerosol indirect effects in the global climate model ECHAM5-HAM, Atmos. Chem. Phys., 7, 3425-3446, https://doi.org/10.5194/acp-7-34252007, 2007.

Mie, G.: Beiträge zur Optik trüber Medien, speziell kolloidaler Metallösungen, Ann. Phys.-Berlin, 330, 377-445, 1908.

Myhre, G., Jonson, J. E., Bartnicki, J., Stordal, F., and Shine, K. P.: Role of spatial and temporal variations in the computation of radiative forcing due to sulphate aerosols: A regional study, Q. J. Roy. Meteor. Soc., 128, 973-989, https://doi.org/10.1256/0035900021643610, 2002.

Myhre, G., Samset, B. H., Schulz, M., Balkanski, Y., Bauer, S., Berntsen, T. K., Bian, H., Bellouin, N., Chin, M., Diehl, T., Easter, R. C., Feichter, J., Ghan, S. J., Hauglustaine, D., Iversen, T., Kinne, S., Kirkevåg, A., Lamarque, J.-F., Lin, G., Liu, X., Lund, M. T., Luo, G., Ma, X., van Noije, T., Penner, J. E., Rasch, P. J., Ruiz, A., Seland, Ø., Skeie, R. B., Stier, P., Takemura, T., Tsigaridis, K., Wang, P., Wang, Z., Xu, L., Yu, H., Yu, F., Yoon, J.-H., Zhang, K., Zhang, H., and Zhou, C.: Radiative forcing of the direct aerosol effect from AeroCom Phase II simulations, Atmos. Chem. Phys., 13, 1853-1877, https://doi.org/10.5194/acp13-1853-2013, 2013.

Petch, J. C.: Using a cloud-resolving model to study the effects of subgrid-scale variations in relative humidity on direct sulphate-aerosol forcing, Q. J. Roy. Meteor. Soc., 127, 23852394, https://doi.org/10.1002/qj.49712757710, 2001.

Petters, M. D. and Kreidenweis, S. M.: A single parameter representation of hygroscopic growth and cloud condensation nucleus activity, Atmos. Chem. Phys., 7, 1961-1971, https://doi.org/10.5194/acp-7-1961-2007, 2007.

Pringle, K. J., Tost, H., Pozzer, A., Pöschl, U., and Lelieveld, J.: Global distribution of the effective aerosol hygroscopicity parameter for $\mathrm{CCN}$ activation, Atmos. Chem. Phys., 10, 52415255, https://doi.org/10.5194/acp-10-5241-2010, 2010.

Quaas, J.: Evaluating the "critical relative humidity" as a measure of subgrid-scale variability of humidity in general circulation model cloud cover parameterizations using satellite data, J. Geophys. Res., 117, D09208, https://doi.org/10.1029/2012JD017495, 2012.

Rosch, J., Heus, T., Brueck, M., Salzmann, M., Mülmenstädt, J., Schlemmer, L., and Quaas, J.: Analysis of diagnostic climate model cloud parametrizations using largeeddy simulations, Q. J. Roy. Meteor. Soc., 141, 2199-2205, https://doi.org/10.1002/qj.2515, 2015.

Shindell, D. T., Lamarque, J.-F., Schulz, M., Flanner, M., Jiao, C., Chin, M., Young, P. J., Lee, Y. H., Rotstayn, L., Mahowald, N., Milly, G., Faluvegi, G., Balkanski, Y., Collins, W. J., Conley, A. J., Dalsoren, S., Easter, R., Ghan, S., Horowitz, L., Liu, X., Myhre, G., Nagashima, T., Naik, V., Rumbold, S. T., Skeie, R., Sudo, K., Szopa, S., Takemura, T., Voulgarakis, A., Yoon, J.-H., and Lo, F.: Radiative forcing in the ACCMIP historical and future climate simulations, Atmos. Chem. Phys., 13, 2939-2974, https://doi.org/10.5194/acp-13-2939-2013, 2013.

Skupin, A., Ansmann, A., Engelmann, R., Seifert, P., and Müller, T.: Four-year long-path monitoring of ambient aerosol extinction at a central European urban site: dependence on relative humidity, Atmos. Chem. Phys., 16, 1863-1876, https://doi.org/10.5194/acp-16-1863-2016, 2016.
Stevens, B., Giorgetta, M., Esch, M., Mauritsen, T., Crueger, T., Rast, S., Salzmann, M., Schmidt, H., Bader, J., Block, K., Brokopf, R., Fast, I., Kinne, S., Kornblueh, L., Lohmann, U., Pincus, R., Reichler, T., and Roeckner, E.: Atmospheric component of the MPI-M Earth System Model: ECHAM6, J. Adv. Model. Earth Syst., 5, 146-172, https://doi.org/10.1002/jame.20015, 2013.

Stier, P., Feichter, J., Kinne, S., Kloster, S., Vignati, E., Wilson, J., Ganzeveld, L., Tegen, I., Werner, M., Balkanski, Y., Schulz, M., Boucher, O., Minikin, A., and Petzold, A.: The aerosol-climate model ECHAM5-HAM, Atmos. Chem. Phys., 5, 1125-1156, https://doi.org/10.5194/acp-5-1125-2005, 2005.

Stier, P., Seinfeld, J. H., Kinne, S., and Boucher, O.: Aerosol absorption and radiative forcing, Atmos. Chem. Phys., 7, 5237-5261, https://doi.org/10.5194/acp-7-5237-2007, 2007.

Sundqvist, H., Berge, E., and Kristjánsson, J. E.: Condensation and cloud parameterization studies with a mesoscale numerical weather prediction model, Mon. Weather Rev., 117, 1641-1657, 1989.

Tiedtke, M.: Representation of clouds in large scale models, Mon. Weather Rev., 121, 3040-3061, 1993.

Tompkins, A. M.: A Prognostic Parameterization for the SubgridScale Variability of Water Vapor and Clouds in LargeScale Models and Its Use to Diagnose Cloud Cover, J. Atmos. Sci., 59, 1917-1942, https://doi.org/10.1175/15200469(2002)059<1917:APPFTS>2.0.CO;2, 2002.

Tompkins, A. M. and Berner, J.: A stochastic convective approach to account for model uncertainty due to unresolved humidity variability, J. Geophys. Res., 113, D18101, https://doi.org/10.1029/2007JD009284, 2008.

Toon, O. B. and Ackerman, T. P.: Algorithms for the calculation of scattering by stratified spheres, Appl. Optics, 20, 3657, https://doi.org/10.1364/AO.20.003657, 1981.

Twohy, C. H., Clarke, A. D., Warren, S. G., Radke, L. F., and Charlson, R. J.: Light-absorbing material extracted from cloud droplets and its effect on cloud albedo, J. Geophys. Res., 94, 8623-8631, https://doi.org/10.1029/JD094iD06p08623, 1989.

Vignati, E., Wilson, J., and Stier, P.: M7: An efficient size-resolved aerosol microphysics module for large-scale aerosol transport models, J. Geophys. Res., 109, D22202, https://doi.org/10.1029/2003JD004485, 2004.

Weigum, N., Schutgens, N., and Stier, P.: Effect of aerosol subgrid variability on aerosol optical depth and cloud condensation nuclei: implications for global aerosol modelling, Atmos. Chem. Phys., 16, 13619-13639, https://doi.org/10.5194/acp-16-136192016, 2016.

Zhang, K., O’Donnell, D., Kazil, J., Stier, P., Kinne, S., Lohmann, U., Ferrachat, S., Croft, B., Quaas, J., Wan, H., Rast, S., and Feichter, J.: The global aerosol-climate model ECHAM-HAM, version 2: sensitivity to improvements in process representations, Atmos. Chem. Phys., 12, 8911-8949, https://doi.org/10.5194/acp-12-8911-2012, 2012.

Zieger, P., Fierz-Schmidhauser, R., Weingartner, E., and Baltensperger, U.: Effects of relative humidity on aerosol light scattering: results from different European sites, Atmos. Chem. Phys., 13, 10609-10631, https://doi.org/10.5194/acp-13-106092013, 2013. 